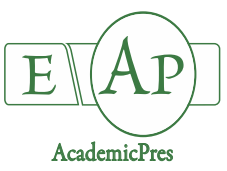

Sevgin Zirek N and Uzal O (2020)

Notulae Botanicae Horti Agrobotanici Cluj-Napoca 48(2):967-977

DOI: $10.15835 /$ nbha48211943

Research Article

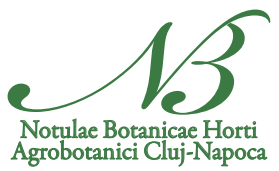

\title{
The developmental and metabolic effects of different magnesium dozes in pepper plants under salt stress
}

\author{
Neslihan SEVGIN ZIREK ${ }^{1}$, Ozlem UZAL ${ }^{2 *}$ \\ ${ }^{1}$ Van Yuzuncu Yil University, Institute of Natural and Applied Sciences, Department of Horticulture, Van, \\ Turkey; Neslihan-sevgin@hotmail.com \\ ${ }^{2}$ Van Yuzuncu Yil University, Faculty of Agriculture, Department of Horticulture, Van, \\ Turkey; ozlemuzal@yyu.edu.tr (*orrespondingauthor); ozlemuzal@yyu.edu.tr
}

\begin{abstract}
Morphological and biochemical effects of different magnesium $(\mathrm{Mg})$ doses on pepper plants under salt stress were investigated in this study. Experiments were conducted under controlled conditions of a climate cabin at $25^{\circ} \mathrm{C}$ temperature, $70 \%$ relative humidity and $16 / 8$ hours light/dark photoperiod. The developmental and metabolic effects of different magnesium doses in plants under salt stress were investigated by examining leaf antioxidant enzyme activities, Malondialdehyde (MDA) levels and chlorophyll contents. Seedlings of 'Demre' pepper cultivar (Capsicum annuum L. cv. 'Demre') were grown in Hoagland nutrient solution supplemented with $100 \mathrm{mM} \mathrm{NaCl}$ to generate salt stress. Besides salt treatments, different $\mathrm{Mg}$ doses $(\mathrm{Mg} 1=$ $24.64 \mathrm{ppm}, \mathrm{Mg} 2=49.28 \mathrm{ppm}, \mathrm{Mg} 3=73.92 \mathrm{ppm}, \mathrm{Mg} 4=98.56 \mathrm{ppm}, \mathrm{Mg} 5=123.20 \mathrm{ppm}$ ) were applied to plants. On the $20^{\text {th }}$ day of salt treatments, the total weight of the plants which is one of the growths and development parameters of pepper plants was measured, and plant samples were taken for analyses. A slight increase was observed in total weights of salt-treated plants with increasing Mg doses. The greatest plant weight was obtained from $\mathrm{Mg} 4+$ salt treatments. It was observed that increasing Mg doses had positive effects on the development of plants under salt stress. Chlorophyll contents and antioxidant enzymes activities increased and MDA (malondialdehyde) levels, the product of lipid peroxidation, which indicates the amount of damage to plant cells, decreased with increasing $\mathrm{Mg}$ doses. Present measurements and analyses and resultant findings revealed that $\mathrm{Mg}$ treatments at increasing doses partially alleviated negative effects of salt stress on pepper seedlings.
\end{abstract}

Keywords: antioxidant enzyme activity; magnesium; oxidative stress; pepper (Capsicum annum L.); salt stress

\section{Introduction}

Salt stress is an abiotic factor negatively influencing various metabolic processes of plants, reducing yield and quality of culture plants. Pepper is largely grown in open fields and greenhouses and salt stress has serious negative impacts also on pepper plants. Salinity is more effective in undercover production sites than open fields. Even in soilless cultures, low quality water resulted in salinity problems (Oztekin and Tuzel, 2011). 
Salinity generally results in reduction in number of leaves and leaf sizes, plant heights, differentiation in tissues and organs, suppression of plant growth and development, unbalanced root and shoot weights, thus week root system and recessed plant root and plant growth. Salinity also reduces plant fresh and dry biomass, chlorophyll content, fruit size and ultimately yield levels (Yu et al., 2012). Salt stress recesses plant growth and development, slows down the photosynthetic activity, increases reactive oxygen species, decreases plant water potential, results in ion unbalance and stomal closure (Bartels and Sunkar, 2005; Yasar et al., 2006a; Mahajan et al., 2008; Yildirim et al., 2008). As explained by Yasar (2003), stress conditions promote the synthesis of free radicals, which in turn damage plant cells and limit photosynthetic activity. Oxygen free radicals especially damage number of cellular components, including proteins, membrane lipids, nucleic acids and chlorophyll amount (Fridovich, 1986; Davies, 1987; Yasar et al., 2006b; Yasar et al., 2014). As it was in the other living organism, free radical levels of the plants are controlled by antioxidants and antioxidant enzyme activities, which convert oxygen free radicals into harmless compounds. A stressed plant will typically become more resistant to oxidative damage, and chloroplasts, which generate oxygen during photosynthesis, constitute key components of antioxidant defense systems that protect plants from destructions of toxic oxygen derivatives. The most effective enzymes that eliminate free oxygen radicals include superoxide dismutase (SOD), ascorbate peroxidase (APX), glutathione reductase (GR), and catalase (CAT) (Cakmak and Manschner, 1992; Cakmak, 1994; Gosset et al., 1994). Significant correlations were reported in previous studies between antioxidant activity and stress tolerance.

The adverse effect of high $\mathrm{NaCl}$ on chlorophyll concentration was previously shown in Yildirim et al. (2008). Magnesium ions are found in the center of chlorophyll molecules. Chlorophyll is a key component of the reaction of photosynthesis, which produces energy for growth. Mg ions are therefore are essential components of photosynthesis. Magnesium also plays a substantial role in phosphorus transport in the plant; it assists in phosphate metabolism, plant respiration, protein synthesis, and activation of several enzyme systems (Marschner, 1995). It was shown that salt stress reduced Mg take of plants (Yildirim et al., 2008). The application of $\mathrm{KNO}_{3}, \mathrm{Mg}\left(\mathrm{NO}_{3}\right)_{2}$ and $\mathrm{Ca}\left(\mathrm{NO}_{3}\right)_{2}$ significantly improved chlorophyll content (Yildirim et al., 2009). Foliar applications of these elements could thus increase the chlorophyll content of plants under salt stress (Yildirim et al., 2009).

Salt stress reduced leaf relative water content (LRWC) of plants as compared to non-salt stress treatments; plant LRWC was reduced by $15 \%$ at $40 \mathrm{mM} \mathrm{NaCl}$. Such reductions were measured as $8.0 \%$ with $10 \mathrm{mM} \mathrm{KNO}_{3}, 8.2 \%$ with $\mathrm{Ca}\left(\mathrm{NO}_{3}\right)_{2}$ and $4.8 \%$ with $\mathrm{Mg}\left(\mathrm{NO}_{3}\right)_{2}$ treatments (Yildirim et al., 2008). It indicates a loss of turgor resulting in limited water availability for the cell-extension process. The application of $\mathrm{KNO}_{3}$, $\mathrm{Mg}\left(\mathrm{NO}_{3}\right)_{2}$ and $\mathrm{Ca}\left(\mathrm{NO}_{3}\right)_{2}$ significantly improved this parameter.

Yildirim et al. (2009) also explained that salinity reduced plant macro and micronutrient contents except for $\mathrm{Na}$ and $\mathrm{Cl}$ content of plant shoots and roots. The foliar application of $\mathrm{KNO}_{3}, \mathrm{Mg}\left(\mathrm{NO}_{3}\right)_{2}$ and $\mathrm{Ca}$ $\left(\mathrm{NO}_{3}\right)_{2}$ increased $\mathrm{N}, \mathrm{K}, \mathrm{Mg}, \mathrm{Ca}, \mathrm{S}$ and $\mathrm{P}$ contents under salinity stress. It is not surprising that supplementary $\mathrm{KNO}_{3}, \mathrm{Mg}\left(\mathrm{NO}_{3}\right)_{2}$ and $\mathrm{Ca}\left(\mathrm{NO}_{3}\right)_{2}$ enhanced concentrations of $\mathrm{N}, \mathrm{K}, \mathrm{Ca}$, and $\mathrm{Mg}$; however, contents of these elements in plants receiving supplementary $\mathrm{KNO}_{3}, \mathrm{Mg}\left(\mathrm{NO}_{3}\right)_{2}, \mathrm{Ca}\left(\mathrm{NO}_{3}\right)_{2}$ were still much lower than those of non-salt stress treatments. Plant inorganic ions were negatively related to salt doses. From the results of this experiment, it can be concluded that $\mathrm{NO}_{3}$ - with $\mathrm{K}, \mathrm{Ca}$ and $\mathrm{Mg}$ counteracted the deleterious effects of salinity stress on the investigated parameters, helped the strawberry plants to avoid $\mathrm{Na}$ toxicity and improved cell membrane stability and nutrient uptake under salinity stress. Improvement of plant growth, water status of salt-stressed strawberry plants makes it possible to recommend the treatment of plants grown under saline conditions with the above chemicals.

Pepper (Capsicum annuum L.) is moderately tolerant to salt stress. Threshold salinity levels for pepper were reported as 1.0-1.5 dS/m and a salinity level of EC $=3.4 \mathrm{dS} / \mathrm{m}$ may result in about $50 \%$ yield loss (Ayers, 1977). Salt resistant species and cultivars should be developed to minimize yield and quality losses or treatments reducing adverse effects of salinity on plants should be used or experimented. 
Magnesium works as an activator of many enzymes involved in energy transfer and growth processes; it is also a key component of chlorophyll and is thus essential for photosynthesis (Bansal, 1989). Mg deficiency primarily affects the metabolism of carbohydrate resulting in reduced plant growth and a decreased transport rate of carbohydrates to sink organs, as reported by Gopikumar and Varghese (2004).

Based on this information, in this study, effects of magnesium $(\mathrm{Mg})$ on antioxidative enzymes, chlorophyll and malondialdehyde (MDA) contents of pepper plants under salt stress were investigated. Besides salt treatments, $\mathrm{Mg}$ was applied at different doses and effects of $\mathrm{Mg}$ treatments under salt stress on plant salt tolerance were investigated.

\section{Materials and Methods}

'Demre' pepper cultivar (Capsicum annuum L. cv. 'Demre') was used as the plant material of this study. Experiments were conducted in a climate cabin with split-air conditioner providing normal atmospheric conditions. Pepper seeds were sown in plastic germination cups filled with pumice and peat soil and irrigated with tap water. Seeds germination cups were placed into a climate cabin at $25 \pm 1{ }^{\circ} \mathrm{C}$ temperature and $70 \%$ relative humidity. When the germinated seedlings had horizontal cotyledon leaves and the first true leaves, irrigations were initiated with the Hoagland nutrient solution (Table 1) (Hoagland and Arnon, 1938). The seedlings with the 2 nd true leaves were surrounded with sponges and transplanted into aqua culture in plastic trays $(25 \times 25 \times 18 \mathrm{~cm})$ filled with nutrient solution. Aeration was provided with an aquarium pomp. Seedlings were grown in aquaculture until they had 4-5 true leaves, then salt treatments were initiated. For salt-treated seedlings, $\mathrm{NaCl}$ was supplemented into nutrient solution (1/2 Hoagland) as to have $100 \mathrm{mM}$ salt concentration. Nutrient solutions were replenished every week as to sustain the same salt concentration. $\mathrm{Mg}$ ratios of Hoagland nutrient solution in which salt-treated seedlings were grown were altered through $\mathrm{MgSO}_{4}$ supplementations at 5 different doses $(\mathrm{Mg} 1=24.64 \mathrm{ppm}, \mathrm{Mg} 2=49.28 \mathrm{ppm}, \mathrm{Mg} 3=73.92 \mathrm{ppm}, \mathrm{Mg} 4=98.56$ ppm, $\mathrm{Mg} 5=123.20 \mathrm{ppm}$ ). Control plants were grown in standard Hoagland nutrient solution with salt treatments.

Table 1. Contents of the nutrient solution used (ppm)

\begin{tabular}{|c|c|c|c|c|c|c|}
\hline Elements & $\begin{array}{c}\text { App. 1 } \\
\text { Control } \\
(\mathrm{ppm})\end{array}$ & $\begin{array}{c}\text { App. 2 } \\
\mathrm{Mg1+NaCl} \\
(\mathrm{ppm})\end{array}$ & $\begin{array}{c}\text { App. 3 } \\
\mathrm{Mg} 2+\mathrm{NaCl} \\
(\mathrm{ppm})\end{array}$ & $\begin{array}{c}\text { App. 4 } \\
\mathrm{Mg3}+\mathrm{NaCl} \\
(\mathrm{ppm})\end{array}$ & $\begin{array}{c}\text { App. 5 } \\
\mathrm{Mg} 4+\mathrm{NaCl} \\
(\mathrm{ppm})\end{array}$ & $\begin{array}{c}\text { App. 6 } \\
\mathrm{Mg} 5+\mathrm{NaCl} \\
(\mathrm{ppm})\end{array}$ \\
\hline Nitrogen $(\mathrm{N})$ & 186 & 186 & 186 & 186 & 186 & 186 \\
\hline Phosphorus $(\mathrm{P})$ & 31 & 31 & 31 & 31 & 31 & 31 \\
\hline Potassium $(\mathrm{K})$ & 167 & 167 & 167 & 167 & 167 & 167 \\
\hline Magnesium $(\mathbf{M g})$ & $\mathbf{4 9 . 2 8}$ & $\mathbf{2 4 . 6 4}$ & $\mathbf{4 9 . 2 8}$ & $\mathbf{7 3 . 9 2}$ & $\mathbf{9 8 . 5 6}$ & $\mathbf{1 2 3 . 2 0}$ \\
\hline Calcium $(\mathrm{Ca})$ & 200 & 150 & 200 & 250 & 300 & 350 \\
\hline Sulfur $(\mathrm{S})$ & 66 & 66 & 66 & 66 & 66 & 66 \\
\hline Iron $(\mathrm{Fe})$ & 3.3 & 3.3 & 3.3 & 3.3 & 3.3 & 3.3 \\
\hline Manganese $(\mathrm{Mn})$ & 0.031 & 0.031 & 0.031 & 0.031 & 0.031 & 0.031 \\
\hline Boron $(\mathrm{B})$ & 0.205 & 0.205 & 0.205 & 0.205 & 0.205 & 0.205 \\
\hline Copper $(\mathrm{Cu})$ & 0.015 & 0.015 & 0.015 & 0.015 & 0.015 & 0.015 \\
\hline Zinc $(\mathrm{Zn})$ & 0.023 & 0.023 & 0.023 & 0.023 & 0.023 & 0.023 \\
\hline
\end{tabular}

At the 20th day of treatments, plant samples were taken and samples were weighed with a precise balance $( \pm 0.0001 \mathrm{~g})$. Chlorophyll and MDA contents and antioxidative enzyme activities (Catalase, Ascorbate Peroxidase, Superoxide dismutase) were determined on plant leaves. 


\section{Chlorophyll analysis}

Leaf segments, either fresh or frozen at $-40{ }^{\circ} \mathrm{C}$, were placed in $5 \mathrm{ml}$ of $80 \%$ ethanol and heated in a water bath at $80^{\circ} \mathrm{C}$ for $20 \mathrm{~min}$. Total chlorophyll was evaluated in the alcohol extracts from absorbance readings, using the appropriate extinction coefficient. Chlorophyll content (mg/g fr wt) was calculated as $1000 \times \mathrm{A} 654$ / $(39.8 \times$ sample fr wt), according to Luna et al. $(2000)$.

\section{Malondialdehyde analysis}

The method defined by Lutts et al. (1996) was employed for measuring the amount of malondialdehyde, which is produced as a result of the lipid peroxidation that causes stress-induced damage to cellular membranes. Malondialdehyde (MDA) concentration was determined by using an "extinction" coefficient, which is 155 $\mathrm{mM}^{-1} \mathrm{~cm}^{-1}$, expressed as $\mu \mathrm{mol} / \mathrm{g}$ fresh weight. The following equation was used in the calculation: $\mathrm{MDA}=(\mathrm{A}$ 523 - A 600) x volume of the extract $(\mathrm{ml}) /(155 \mathrm{mM} / \mathrm{cm} \times$ sample amount $)$.

\section{Enzyme extraction and assay}

Fresh leaf samples were submersed for $5 \mathrm{~min}$ in liquid nitrogen. The frozen leaves were kept at $-80{ }^{\circ} \mathrm{C}$ for further analyses. Enzymes were extracted from $0.5 \mathrm{~g}$ leaf tissue using a mortar and pestle with $5 \mathrm{ml}$ extraction buffer containing $50 \mathrm{mM}$ potassium phosphate buffer $\mathrm{pH}$ 7.6- and 0.1-mM Na-EDTA. The homogenate was centrifuged at 15,000 $\mathrm{g}$ for $15 \mathrm{~min}$ and the supernatant fraction was used for the various enzyme assays. All steps in the preparation of enzyme extracts were performed at $4{ }^{\circ} \mathrm{C}$.

SOD was assayed according to Cakmak and Marschner (1992), by monitoring the superoxide radicalinduced nitro blue tetrazolium reduction (NBT) at $560 \mathrm{~nm}$. One unit of SOD activity was defined as the amount of enzyme that causes $50 \%$ inhibition of the photochemical reduction of NBT. Catalase activity was determined by monitoring the disappearance of $\mathrm{H}_{2} \mathrm{O}_{2}$ according to the method of Cakmak and Marschner (1992). APX activity was determined by measuring the consumption of ascorbate by following absorbance at $290 \mathrm{~nm}$ Cakmak and Marschner (1992). One unit of APX activity was defined as the amount of enzyme required to consume $1 \mu \mathrm{mol}$ ascorbate $\mathrm{min}^{-1}$.

The experiment was designed as a completely randomized plot with three replicates. Data were analyzed statistically, and the means of each treatment were analyzed by Duncan's multiple range test using SAS software (1985).

\section{Results and Discussion}

Total weights of salt-treated plants under $\mathrm{NaCl}$ stress were weighed at the end of $20^{\text {th }}$ day and resultant values are provided in Table 2.

As compared to the control plants, significant decreases were observed in total weight of salt-treated plants at the end of 20-day salt stress. Among the salt-treated plants, the greatest plant weights were observed in $\mathrm{Mg} 4+$ salt and $\mathrm{Mg} 3$ + salt treatments. However, plant weights of these treatments were placed into the same statistical group with the control plants. The lowest plant weights were obtained from $\mathrm{Mg} 1+$ salt and $\mathrm{Mg} 2+$ salt treatments. Plant weights of $\mathrm{Mg} 1+$ salt, $\mathrm{Mg} 2+$ salt and $\mathrm{Mg} 3$ + salt treatments were all placed into the same statistical group.

Munns and Termaat (1986) reported that plant growth was negatively influenced by salt stress. In present study conducted with the assumption of potential reduction in the effects of salt stress on plant growth, positive effects of $\mathrm{Mg}$ treatments were observed on plant growth under salt stress with increasing $\mathrm{Mg}$ doses.

Cell membrane damages and lipid peroxidation byproduct (MDA) contents are commonly used as an indicator of salt stress-induced oxidative damage. As compared to the control treatments, increases were observed in MDA content of salt-treated plants. The greatest MDA content was obtained from Mg $1+$ salt treatments and the lowest value was obtained from $\mathrm{Mg} 4+$ salt treatments (Table 3). In terms of negative effects 
of salt treatments based on MDA contents, the greatest effects were observed in Mg $1+$ salt treatments and the least effects were observed in $\mathrm{Mg} 4+$ salt treatments.

Table 2. Effects of different Mg doses on total weight of pepper seedlings

\begin{tabular}{|c|c|c|c|c|c|c|}
\hline \multicolumn{7}{|c|}{ Treatments } \\
\hline & Control & $\mathrm{Mg} 1+\mathrm{NaCl}$ & $\mathrm{Mg} 2+\mathrm{NaCl}$ & $\mathrm{Mg} 3+\mathrm{NaCl}$ & $\mathrm{Mg} 4+\mathrm{NaCl}$ & $\mathrm{Mg} 5+\mathrm{NaCl}$ \\
\hline $\begin{array}{l}\text { Total plant } \\
\text { weight }(\mathrm{g})\end{array}$ & $17.149 \mathrm{~A}$ & $9.422 \mathrm{~B}$ & $9.543 \mathrm{~B}$ & $10.117 \mathrm{AB}$ & $10.953 \mathrm{AB}$ & $9.722 \mathrm{~B}$ \\
\hline
\end{tabular}

Means indicated with the same capital letter in the same line are not significantly different $(\mathrm{P} \leq 0.05)$.

Table 3. Leaf MDA and chlorophyll contents ( $\mu \mathrm{mol} / \mathrm{g}$ F.W.) of plants

\begin{tabular}{|c|c|c|}
\hline Treatments & MDA & Chlorophyll \\
\hline Control & $2.9950 \mathrm{D}$ & $4.9433 \mathrm{C}$ \\
\hline $\mathrm{Mg} 1+\mathrm{NaCl}$ & $6.4950 \mathrm{~A}$ & $3.6963 \mathrm{D}$ \\
\hline $\mathrm{Mg} 2+\mathrm{NaCl}$ & $4.9033 \mathrm{~B}$ & $5.5007 \mathrm{BC}$ \\
\hline $\mathrm{Mg} 3+\mathrm{NaCl}$ & $4.0553 \mathrm{~B}-\mathrm{D}$ & $6.7787 \mathrm{~A}$ \\
\hline $\mathrm{Mg} 4+\mathrm{NaCl}$ & $3.6373 \mathrm{CD}$ & $6.8137 \mathrm{~A}$ \\
\hline $\mathrm{Mg} 5+\mathrm{NaCl}$ & $4.5913 \mathrm{BC}$ & $6.1690 \mathrm{AB}$ \\
\hline
\end{tabular}

Means indicated with the same capital letter in the same column are not significantly different $(\mathrm{P} \leq 0.05)$.

\section{Total plant weight $(g)$}

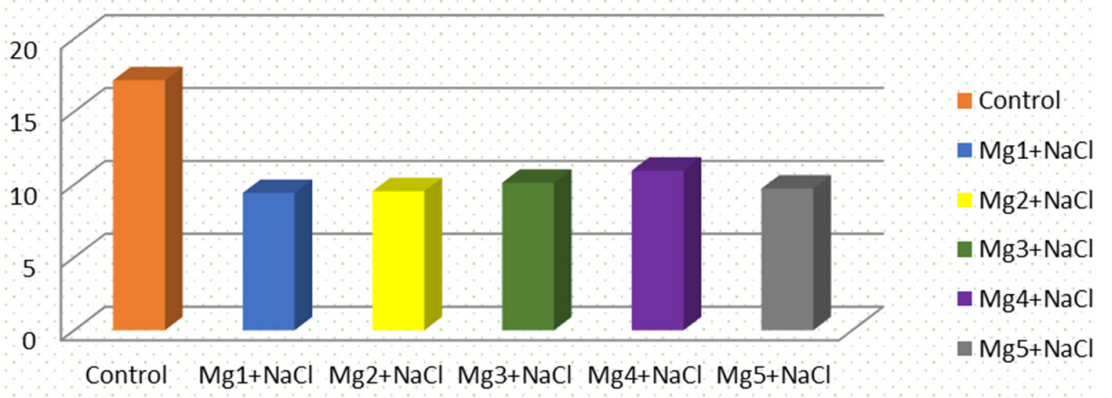

Figure 1. Effects of applications on the total weight of plants

Malondialdehyde (MDA) is a byproduct of lipid peroxidation and it is released when the cell membrane was damaged. High MDA levels indicate damaged cell membrane and low MDA levels indicate undamaged or slightly damaged cell membrane (Yaşar, 2003). Yaşar et al. (2007) conducted a study on watermelon and reported positive correlations between scale values and MDA contents and indicated high MDA values for genotypes with high scale values and low MDA values for salt-effected genotypes with low scale values. Similar findings were also reported by Shalata and Tal (1998) for tomato, by Aktaş (2002) for pepper and by Kusvuran et al. (2008) for Cucumis sp. genotypes. In present study, increasing Mg doses partially reduced the negative effects of salt stress on plants. Oxidative damage destroys the structure of chlorophyll and thus reduce leaf chlorophyll contents.

As compared to control plants, increase and decreases were observed in chlorophyll contents of salttreated plants for 20 days. The greatest chlorophyll content was obtained from $\mathrm{Mg} 4+$ salt treatments and the lowest chlorophyll content was obtained from Mg $1+$ salt treatments (Figure 2). 


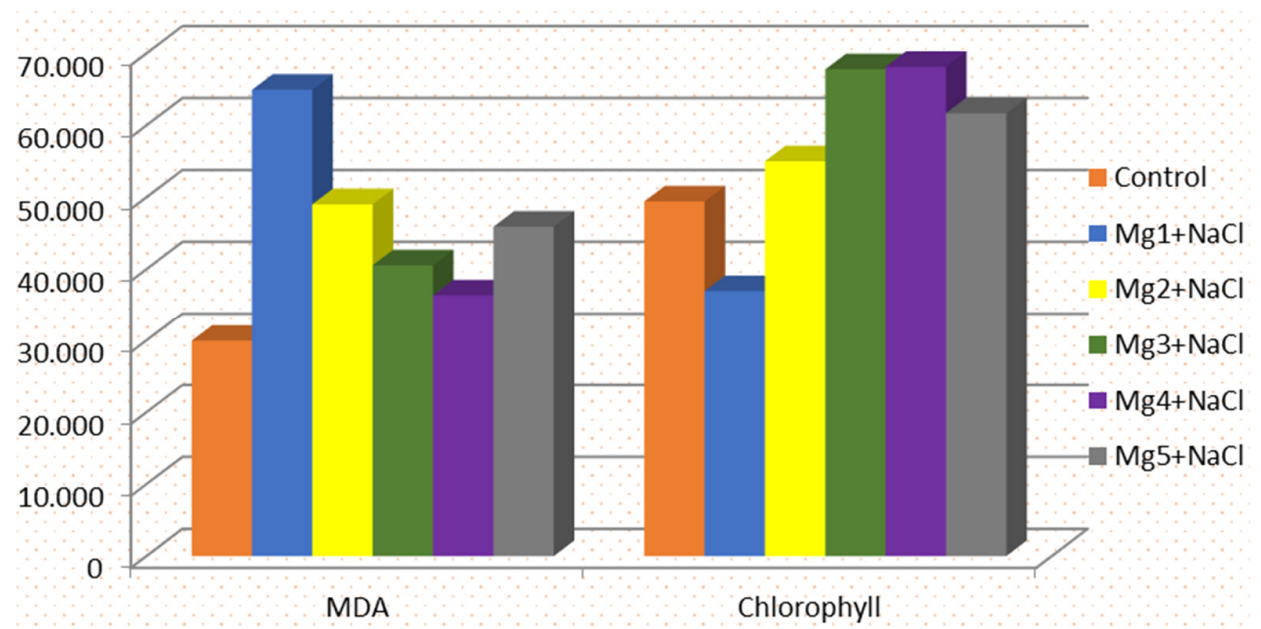

Figure 2. Effects of applications on the MDA and chlorophyll contents

$\mathrm{Mg}$ functions as a central atom of chlorophyll molecule in photosynthesis (Papenbrock et al., 2000). Therefore, it is essential for chlorophyll synthesis. Similar to Ca, it was reported that greater than normal Mg levels served a protective function against adverse environmental conditions in plant tissues (Hecht-Buchholtz and Schuster, 1987). Under salt stress, disruption of general metabolic processes, limited uptake of macro and micronutrients like Ca, K, N, P and Mg negatively influence chlorophyll formation. Negative effects of salt stress on chlorophyll contents were reported by Turhan et al. (2006) in sunflower and by Yaşar (2003) in eggplant. Salt stress-induced chlorosis on leaves is also resulted from chlorophyll degradation by free oxygen radicals (Üzal, 2009). Yakıt and Tuna (2006) reported that total chlorophyll and carotenoid contents significantly decreased with $\mathrm{NaCl}$ treatments, but $\mathrm{Ca}, \mathrm{K}$ and $\mathrm{Mg}$ supplementations into nutrient solution alleviated such negative effects of $\mathrm{NaCl}$ on chlorophyll and carotenoid contents. Çiçek and Çakırlar (2002) and Gadallah (1999) also reported decreasing chlorophyll contents induced by distortions in general metabolic processes under salt stress. It was reported in another study conducted on peppers that external $\mathrm{KNO}_{3}$ treatments increased leaf and root $\mathrm{K}$ and chlorophyll contents of salt-treated plants and alleviated the negative effects of stress parameters on plant growth and development (Kaya and Higgs, 2003). The greatest chlorophyll contents were respectively observed in $\mathrm{Mg} 4+$ salt, $\mathrm{Mg} 3$ + salt and $\mathrm{Mg} 5$ + salt treatments and they were all placed into the same statistical group. Increasing $\mathrm{Mg}$ doses also reduced the incidence of chlorosis and necrosis on the leaves of salt-treated plants and such a rehabilitating effect was revealed as an increase in chlorophyll content.

As compared to control plants, significant changes were observed in catalase (CAT) enzyme activity of salt-treated plants (Figure 3). In terms of catalyze enzyme activity, $\mathrm{Mg} 1+$ salt, $\mathrm{Mg} 2+$ salt and $\mathrm{Mg} 3+$ salt treatments were placed into the same statistical group. The greatest catalase enzyme activity was obtained from $\operatorname{Mg} 4+$ salt and $\mathrm{Mg} 5$ + salt treatments and the lowest value from $\mathrm{Mg} 2$ + salt treatments (Table 4).

As compared to control plants, increases were observed in ascorbate peroxidase enzyme activity of salttreated plants. The greatest ascorbate peroxidase enzyme activity was obtained from $\mathrm{Mg} 5+$ salt treatments and the lowest value was obtained from Mg $1+$ salt treatments (Table 4, Figure 4).

As compared to control treatment, significant decreases were observed in superoxide dismutase enzyme activity of salt-treated plants in $\mathrm{Mg} 1+$ salt and $\mathrm{Mg} 2+$ salt treatments. In terms of superoxide dismutase enzyme activity, $\mathrm{Mg} 3+$ salt and $\mathrm{Mg} 4+$ salt treatments were placed into the same statistical group. The greatest value was obtained from $\mathrm{Mg} 5+$ salt treatments and the lowest value from $\mathrm{Mg} 2+$ salt treatments followed by Mg $1+$ salt treatments (Table 4, Figure 5). 
Table 4. Leaf catalase (CAT), ascorbate peroxidase (APX) and superoxide dismutase (SOD) enzyme activities of plants ( $\mathrm{mol} / \mathrm{min} / \mathrm{mg} \mathrm{F.W.)}$

\begin{tabular}{|c|c|c|c|}
\hline Treatments & CAT & APX & SOD \\
\hline Control & $3071.5 \mathrm{C}$ & $4.5900 \mathrm{D}$ & $113.333 \mathrm{~B}$ \\
\hline $\mathrm{Mg} 1+\mathrm{NaCl}$ & $2651.8 \mathrm{D}$ & $5.4367 \mathrm{CD}$ & $82.667 \mathrm{D}$ \\
\hline $\mathrm{Mg} 2+\mathrm{NaCl}$ & $2533.9 \mathrm{D}$ & $6.8267 \mathrm{BC}$ & $68.333 \mathrm{E}$ \\
\hline $\mathrm{Mg} 3+\mathrm{NaCl}$ & $2598.0 \mathrm{D}$ & $7.3200 \mathrm{~B}$ & $100.667 \mathrm{C}$ \\
\hline $\mathrm{Mg} 4+\mathrm{NaCl}$ & $4403.0 \mathrm{~A}$ & $7.9600 \mathrm{~B}$ & $107.333 \mathrm{BC}$ \\
\hline $\mathrm{Mg} 5+\mathrm{NaCl}$ & $3480.2 \mathrm{~B}$ & $12.9200 \mathrm{~A}$ & $141.333 \mathrm{~A}$ \\
\hline
\end{tabular}

Means indicated with the same capital letter in the same column are not significantly different $(\mathrm{P} \leq 0.05)$.

\section{CAT}

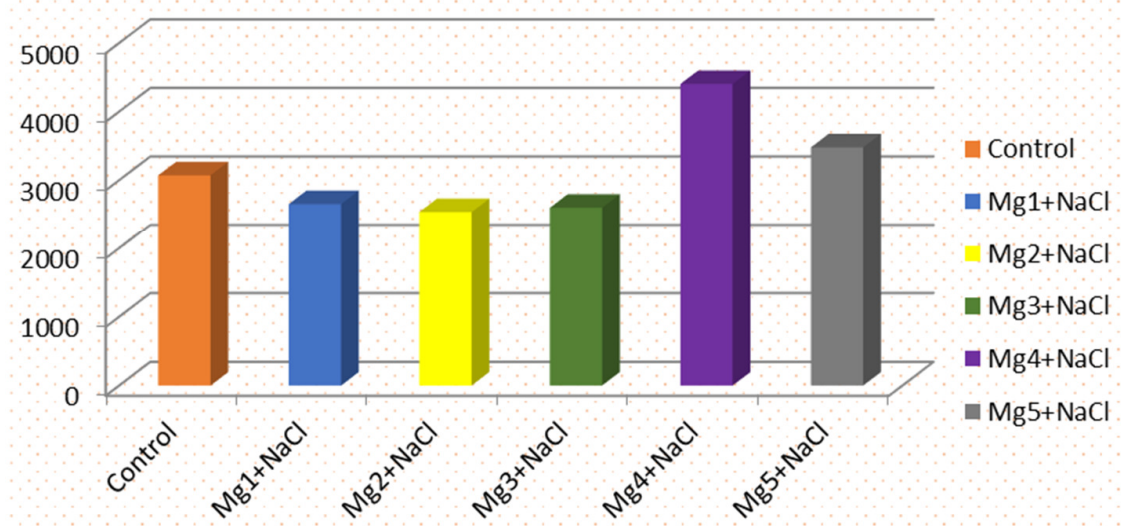

Figure 3. Leaf catalase (CAT) enzyme activities of plants

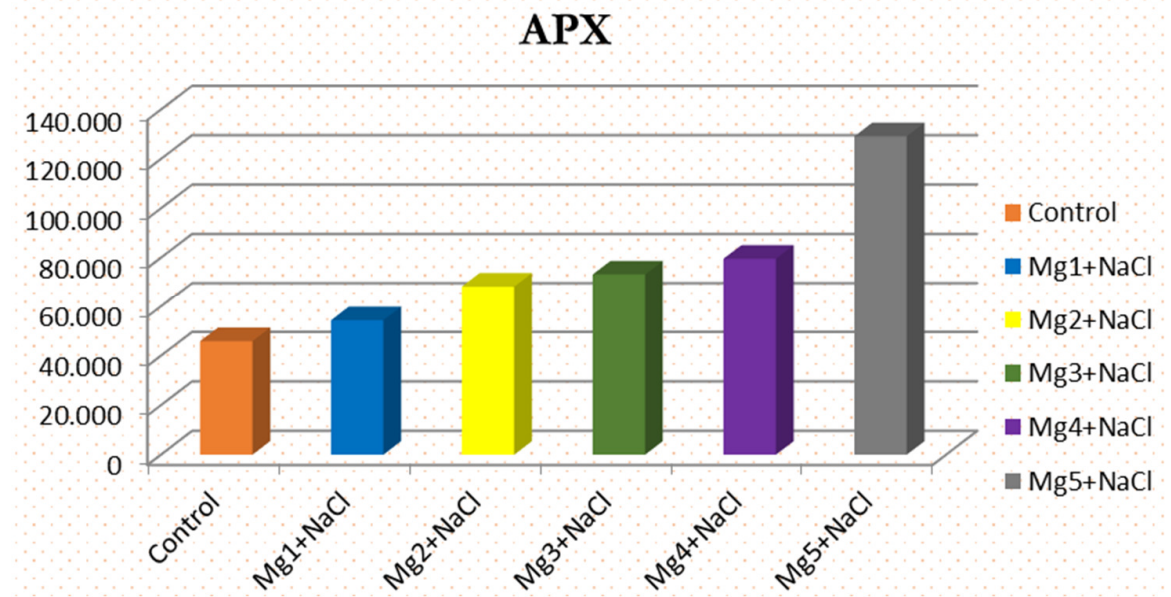

Figure 4. Leaf ascorbate peroxidase (APX) enzyme activities of plants 


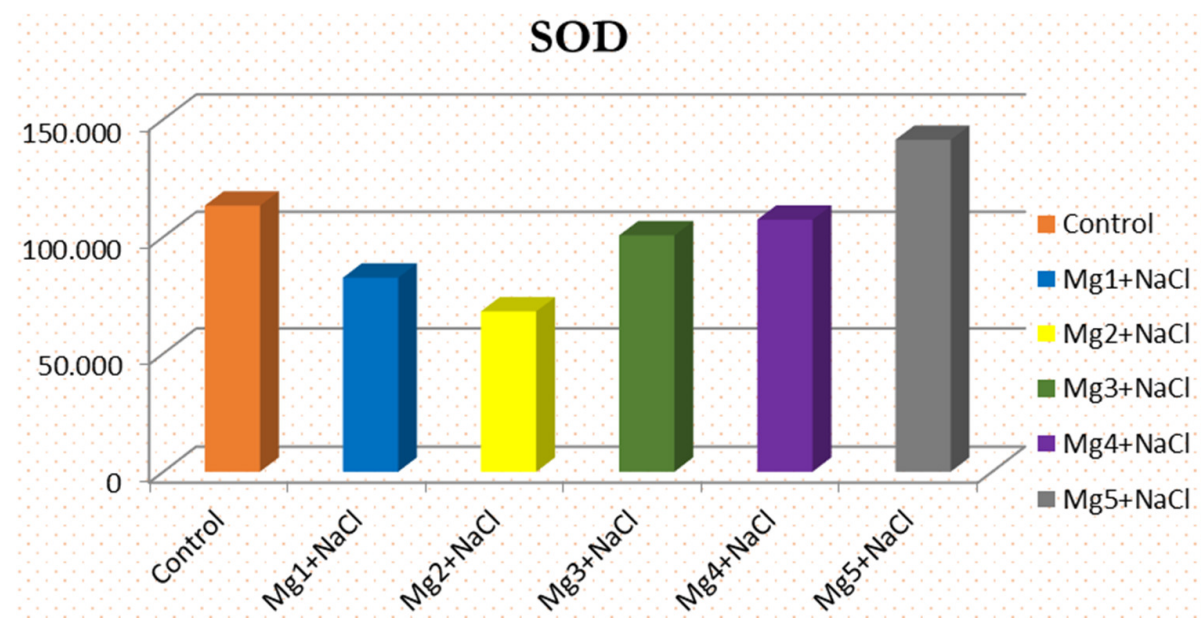

Figure 5. Leaf Superoxide dismutase (SOD) enzyme activities of plants

Significant correlations were reported between increase in antioxidant enzyme activities and decrease in oxidative stress-induced damages in plants under stress conditions (Yaşar et al., 2006b; Yıldız et al., 2010; Uzal et al., 2019). Increasing antioxidant enzyme activities were also reported for different plant species under stress conditions and such increases generally varied based on plant genetics (Türkan et al., 2005; Yasar et al., 2008 a,b; Kuşvuran et al., 2012; Yasar et al., 2016; Uzal et al., 2019). Kusvuran et al. (2008) investigated salt tolerance of some Cucumis sp. genotype and indicated that salt-tolerant genotypes had high enzyme activity and saltsensitive genotypes had low enzyme activities. Similar findings were also reported by Aktaş (2002) and Karanlık (2001). In present study, it was observed that increasing $\mathrm{Mg}$ doses alleviated adverse effects of salt treatments on plants. Therefore, the least enzyme activity was measured in $\mathrm{Mg} 1+$ salt treatment with the least $\mathrm{Mg}$ dose. On the other hand, the greatest enzyme activities were measured in $\mathrm{Mg} 4+$ salt, $\mathrm{Mg} 5+$ salt and $\mathrm{Mg} 3+$ salt treatments with greater $\mathrm{Mg}$ doses.

\section{Conclusions}

In conclusion; this study besides salt treatments, $\mathrm{Mg}$ was applied at different doses and effects of $\mathrm{Mg}$ treatments under salt stress on plant salt tolerance were investigated. In present study conducted with the assumption of potential reduction in the effects of salt stress on plant growth, positive effects of $\mathrm{Mg}$ treatments were observed on plant growth under salt stress with increasing Mg doses. In present study, Mg applied in different doses remarkably changed some antioxidant enzyme activities of salt-treated plants. Present measurements and analyses and resultant findings revealed that $\mathrm{Mg}$ treatments at increasing doses partially alleviated negative effects of salt stress on pepper seedlings.

\section{Authors' Contributions}

The authors declare that they have contributed equally to the article. All authors read and approved the final manuscript. 


\section{Acknowledgements}

This work was supported by the Van Yuzuncu Yil University, Scientific Research Projects Department (Project No: FYL2016-5148). This study was a part of MSc thesis of the first author.

\section{Conflict of Interests}

The authors declare that there are no conflicts of interest related to this article.

\section{References}

Aktaş H (2002). Biberde tuza dayanıklılığın fizyolojik karakterizasyonu ve kalıtımı. Çukurova Üniversitesi, Fen Bilimleri Enstitüsü, Doktora Tezi, Adana, 105 s (in Turkish).

Ayers RS (1977). Quality of water for irrigation. Journal of the irrigation and Drainage Division 103:135-154.

Bansal RI (1989). Effect of $\mathrm{Zn}, \mathrm{B}$ and $\mathrm{Mn}$ application on the yield and content in berseem (Trifolium alexandrinum) grown in an alkaline soil. Acta Agronomica Hungarica 38:353-356.

Bartels D, Sunkar R (2005). Drought and salt tolerance in plants. Critical Reviews in Plant Sciences 24:23-58. https://doi.org/10.1080/07352680590910410

Cakmak I, Marschner H (1992). Magnesium deficiency and highlight intensity enhance activities of superoxide dismutase, ascorbate peroxidase and glutathione reductase in bean leaves. Plant Physiology 98:1222-1226. https://doi.org/10.1104/pp.98.4.1222

Cakmak I (1994). Activity of ascorbate-dependent $\mathrm{H}_{2} \mathrm{O}_{2}$ scavenging enzymes and leaf chlorosis are enhanced in magnesium and potassium deficient leaves, but not in phosphorus deficient leaves. Journal of Experimental Botany 45:1259-1266. https://doi.org/10.1093/jxb/45.9.1259

Çiçek N, Çakırlar H (2002). The effect of salinity on some physiological parameters in two maize cultivars. Bulgarian Journal of Plant Physiology 28(1-2):66-74.

Davies KJA (1987). Protein damage and degradation by oxygen radicals. 1. General Aspects. Journal of Biological Chemistry 262:9895-9901.

Fridovich I (1986). Biological effects of the superoxide radical. Archives of Biochemistry and Biophysics 274:1-11. https://doi.org/10.1016/0003-9861(86)90526-6

Gadallah MAA (1999). Effects proline and glycinebetaine on Vicia faba responses to salt stress. Biologia Plantarum 42:249-257.

Gopikumar K, Varghese V (2004). Sand culture studies of teak (Tectona grandis) in relation to nutritional deficiency symptoms, growth and vigour. Journal of Tropical Forest Science 16:46-61.

Gossett DR, Millhollon EP, Lucas MC (1994). Antioxidant response to $\mathrm{NaCl}$ stress in salt-tolerant and salt-sensitive cultivars of cotton. Crop Science 34:706-714. https://doi.org/10.2135/cropsci1994.0011183X003400030020x

Hecht-Buchholtz C, Schuster J (1987). Responses of al-tolerant Dayton and Al-sensitive Kearney barley cultivars to calcium and magnesium during al stress. Plant and Soil 99:47-61.

Hoagland DR, Arnon DI (1938). The water culture method for growing plants without soil. Circular California Agricultural Experiment Station 1:347-461.

Karanlık S (2001). Değişik buğday genotiplerinde tuz stresine dayanıklılık ve dayanıklılığın fizyolojik nedenlerinin araştırılması.(doktora tezi, basılmamış). Çukurova Üniversitesi Fen Bilimleri Enstitüsü Adana (in Turkish)

Kaya C, Higgs D (2003). Supplementary $\mathrm{KNO}_{3}$ improves salt tolerance in bell pepper plants. Journal of Plant Nutrition 26(7):1367-1382. https://doi.org/10.1081/PLN-120021048

Kusvuran S, Yasar F, Abak K, Ellialtioglu S (2008). Changes occur in lipid peroxidation, chlorophyll and ion contents of some salt tolerant and sensitive Cucumis sp. genotypes grown under salinity stress. Yüzüncü Yıl University Journal of Agricultural Sciences 18(1):13-20. 
Kusvuran S, Ellialtioglu S, Yasar F, Abak K (2012). Antioxidative enzyme activities in the leaves and callus tissues of salttolerant and salt-susceptible melon varieties under salinity. African Journal of Biotechnology 11(3)635-641. https://doi.org/10.5897/AJB11.2119

Luna C, Seffino LG, Arias C, Taleisnik E (2000). Oxidative stress indicators as selection tools for salt tolerance in Chloris gayana. Plant Breeding 119:341-345. https://doi.org/10.1046/j.1439-0523.2000.00504.x

Lutts S, Kinet JM, Bouharmont J (1996). NaCl-induced senescence in leaves of rice (Oryza sativa L.) cultivars differing in salinity resistance. Annals of Botany 78:389-398. https://doi.org/10.1006/anbo.1996.0134

Marschner H (1995). Mineral nutrition of higher plants. Academic Press, London.

Mahajan S, Pveey GK, Tuteja N (2008). Calcium- and salt-stress signalling in plants: shedding light on SOS pathway. Archives of Biochemistry and Biophysics 471(2):146-158. https://doi.org/10.1016/j.abb.2008.01.010

Munns R,Termaat A (1986). Whole-plant responses to salinity. Australian Journal of Plant Physiology 13:143-160. https://doi.org/10.1071/PP9860143

Oztekin GB, Tuzel Y (2011). Salinity response of some tomato rootstocks at seedling stage. African Journal of Agricultural Research 6(20):4726-4735. https://doi.org/10.5897/AJAR11.1164

Papenbrock J, Mock HP, Tanaka R, Kruse E, Grimm B (2000). Role of magnesium chelatase activity in the early steps of the tetrapyrrole biosynthetic pathway. Plant Physiology 122:1161-1169. https://doi.org/10.1104/pp.122.4.1161

Sas-Institue (1985). Sas/State User's Guide 6. 03 ed. SAS. Institute. Cary, North Carolina.

Shalata A, Tal M (1998). The effect of salt stress on lipid peroxidation and antioxidants in the leaf of the cultivated tomato and its wild salt-tolerant relative Lycopersicon pennellii. Physiologia Plantarum 104:169-174. https://doi.org/10.1034/j.1399-3054.1998.1040204.x

Turhan H, Genç L, Bostancı YB, Sümer A, Kavdır Y, Türkmen OS, Killi D (2006). Tuz stresinin ayçiçeği (Helianthus annuus L.) üzerine etkilerinin yansıma teknikleri yardımıyla belirlenmesi.1.Uzaktan Algılama-CBS Çalıştay ve Paneli. 27 Kasım. İstanbul Teknik Üniversitesi. İstanbul.

Türkan İ, Bor M, Özdemir F, Koca H (2005). Differential responses of lipid peroxidation and antioxidants in the leaves of drought-tolerant $P$. acutifolius Gray and drought - sensitive $P$. vulgaris L. subjected to polyethylene glycol mediated water stress. Plant Science 168:223-231. https://doi.org/10.1016/j.plantsci.2004.07.032

Üzal O (2009). Tuz stresi altında yetiştirilen bazı çilek çeşitlerinde jasmonik asitin bitki gelişimi ve antioksidant enzim aktiviteleri üzerine etkisi (Doktora Tezi). Yüzüncü Yıl Üniversitesi. Fen Bilimleri Enstitüsü, Van (in Turkish).

Uzal O, Yasar F, Yasar O (2019). Effects of different doses of exogenous gibberellic acid on total plant weight, lipid peroxidation, and antioxidant enzyme activities of eggplant seedling under salt stress. Fresenius Environmental Bulletin 28(11A):8378-8382.

Yakıt S, Tuna AL (2006). Tuz stresi altındaki mısır bitkisinde (Zea mays L.) stres parametreleri üzerine Ca, Mg ve K'nın etkileri. Akdeniz Üniversitesi Ziraat Fakültesi Dergisi 19(1):59-67 (in Turkish).

Yaşar F (2003). Tuz stresi altındaki patlıcan genotiplerinde bazı antioksidant enzim aktivitelerinin in vitro ve in vivo olarak incelenmesi. (doktora tezi basılmamış). Yüzüncü Yıl Üniversitesi Fen Bilimleri Enstitüsü, Van (in Turkish).

Yasar F, Uzal O, Tufenkci S, Yildiz K (2006a). Ion accumulation in different organs of green bean genotypes grown under salt stress. European Journal of Horticultural Science 71:169-172.

Yaşar F, Kuşvuran S, Ellialtıŏlu S (2006b). Determination of antioxidant activities in some melon (Cucumis melo L.) varieties and cultivars under salt stress. Journal of Horticultural Sciences and Biotechnology 81(4):627-630. https://doi.org/10.1080/14620316.2006.11512115

Yaşar F, Ellialtıŏlu Ş, Ozpay T, Üzal Ö. (2007). Karpuz (Citrillus lanatus) genotiplerinde, tuz stresinden kaynaklanan oksidatif zararlanmanın zamana göre değişimi ve skala ile ilişkisinin belirlenmesi. Yüzüncü Yıl Üniversitesi Fen Bilimleri Enstitüsü Dergisi 12:59-64 (in Turkish).

Yasar F, Ellialtıoglu S, Yıldız K (2008a). Effect of salt stress on antioxidant defense systems, lipid peroxidation, and chlorophyll content in green bean. Russian Journal of Plant Physiology 55:782-786.

Yaşar F, Üzal Ö, Özpay T, Ellialtıoglu Ş (2008b). Tuz stresinin karpuzda (Citrullus lanatus (Thunb) Mansf.) antioksidatif enzim (SOD, CAT, APX ve GR) aktivitesi üzerine etkisi, Yüzüncü Yıl Üniversitesi Ziraat Fakültesi Tarım Bilimleri Dergisi (YYU J AGR SCI) 18:51-55 (in Turkish).

Yasar F, Uzal O, Kose S, Yasar O, Ellialtioglu S (2014). Enzyme activities of certain pumpkin (Cucurbita spp) species under drought stress, Fresenius Environmental Bulletin 23(4):1093-1099. 
Yasar F, Uzal O, Yasar O (2016). Antioxidant enzyme activities and lipid peroxidation amount of pea varieties (Pisum sativum sp. arvense L.) under salt stress. Fresenius Environmental Bulletin 2:37-42.

Yildirim E, Karlidag H, Turan M (2009). Mitigation of salt stress in strawberry by foliar K, Ca and Mg nutrient supply. Plant, Soil and Environment 55(5):213-221.

Yildirim E, Turan M, Guvenc I (2008). Effect of foliar salicylic acid applications on growth, chlorophyll and mineral content of cucumber (Cucumis sativus L.) grown under salt stress. Journal of Plant Nutrition 31:593-612. https://doi.org/10.1080/01904160801895118

Yıldız M, Terzi H, Cenkçi S, Terzi ESA, Uruşak B (2010). Bitkilerde tuzluluğa toleransın fizyolojik ve biyokimyasal markörleri. Anadolu Üniversitesi Bilim ve Teknoloji Dergisi - C Yaşam Bilimleri ve Biyoteknoloji 1(1):1-33 (in Turkish).

Yu S, Wang W, Wang B (2012). Recent progress of salinity tolerance research in plants. Russian Journal of Genetics 48(5):497-505.
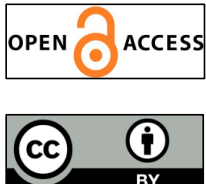

The journal offers free, immediate, and unrestricted access to peer-reviewed research and scholarly work. Users are allowed to read, download, copy, distribute, print, search, or link to the full texts of the articles, or use them for any other lawful purpose, without asking prior permission from the publisher or the author.

License - Articles published in Notulae Botanicae Horti Agrobotanici Cluj-Napoca are Open-Access, distributed under the terms and conditions of the Creative Commons Attribution (CC BY 4.0) License.

(c) Articles by the authors; UASVM, Cluj-Napoca, Romania. The journal allows the author(s) to hold the copyright/to retain publishing rights without restriction. 